\title{
ON NAMES AND PLACE NAMES
}

EVERYONE WHO WRITES ABOUT Burma, now also called Myanmar, is confronted with the unusual issue of what to call the country. In 1989, the ruling military junta officially changed many of the country's place names, and that of the country itself (from Burma to Myanmar). Confusion has reigned ever since. Most people in the country now call it Myanmar, but Burma is still mainly used outside the country, particularly in Britain and America.

Changing the place names was a political decision, part of a programme of 'Burmanisation', and the full context of this is described in Chapter Three. For reasons that I make clear in the text I have chosen to remain with the country's former designation as Burma. I also use the original "colonial-era" names to describe those towns, cities and other places that I write about during that period, for the sake of historical authenticity. This is a list of the eight administrative regions (of fourteen) that were changed in 1989:

Arakan to Rakhine

Irrawaddy to Ayeyarwady

Karen to Kayin

Karenni to Kayah

Magwe to Magway

Pegu to Bago

Rangoon to Yangon

Tenasserim to Tanintharyi 
A very good and full explanation of the name changes, and a useful introduction to the toponymy of Burma in general, can be found at http://webarchive. nationalarchives.gov.uk/20140402150947/http://www.pcgn.org.uk/ burma\%200907.pdf.

To clarify a further potential area for confusion, the word Burman is used here to describe the largest ethnic group in the country. Depending on the context, Burmese either describes all the people of Burma (that is, the Burmans as well as the Kachin, Karen and the hundred or so other ethnic groups who live in the country), or is simply used as the plural of Burman.

Burmese personal names are equally resistant to customary Western notions of how they should be rendered. Usually, Burmese names cannot be separated into a family name and a given name; they function only as a whole. Honorifics are also something of a problem. They are often used in Burma, most commonly $\mathrm{U}$ or Maung in front of a man's name, and Ma or Daw in front of a woman's name (thus Aung San Suu Kyi is often referred to as Daw Suu Kyi). I have chosen not to use them, except in circumstances where it would be difficult to identify them without the honorific. $\mathrm{Nu}$, for example, the first prime minister of independent Burma, is always called $\mathrm{U}$ Nu. 